\title{
Parental Involvement in the School Unit: A Case Study
}

\author{
Pelagia A. Stravakou*
}

Assistant Professor, Department of Primary Education, Democritus University of Thrace, Greece Nea Chili Alexandroupolis GR68100, Greece

DOI: $\underline{10.36348 / \text { sjhss.2020.v05i02.006 }}$ | Received: 05.02.2020|Accepted: 13.02 .2020 | Published: 29.02 .2020

*Corresponding author: Pelagia A. Stravakou

\section{Abstract}

The case study seeks to explore the issue of parental involvement /intervention in the primary and secondary teachers' work in Greece, in order to both the cases which contribute to a favorable and pleasant school climate that effectively helps the teachers' work and the problems and difficulties that do not contribute positively to the work of the teacher and the school unit in general to be identified. For the conduct of this study, twenty five postgraduate students who are simultaneously teachers were recruited. As a research tool written texts were used, while the texts were analyzed by the qualitative content analysis. Overall, findings indicated that Greek parents are most of the times involved in the teachers' work and in school units in general wrongfully, without having the appropriate and adequate pedagogical knowledge, while, on the other hand, teachers behave appropriately, from a pedagogical stance, as they deal with the parental involvement.

Keywords: parental involvement, teachers' work, parents - school collaboration, school effectiveness, case study, qualitative content analysis.

Copyright @ 2020: This is an open-access article distributed under the terms of the Creative Commons Attribution license which permits unrestricted use, distribution, and reproduction in any medium for non-commercial use (NonCommercial, or CC-BY-NC) provided the original author and source are credited.

\section{INTRODUCTION}

The present study investigates the issue of parents' involvement / intervention in teachers of the two school grades, in order both for the cases that create a favorable and pleasant school climate which effectively helps the teachers' work, and the problems and difficulties that do not contribute positively to the work of the teacher and the school unit in general to be identified.

It is clarified, although it is well known, that these two concepts, 'intervention' and 'involvement', have largely different meanings, negative and positive respectively.

Specifically, while parental involvement is considered to have a positive impact on the educational activities of a school unit, therefore, its implementation, promotion and cultivation are considered necessary, parental intervention is characterized as a negative event because it aims more to the personal benefit of their children and not to the improvement of school unit's educational work.

The enforcement of involvement is considered necessary and especially essential in countries where the school unit is characterized by full autonomy and in this context teacher recruitment, teaching and learning contents, textbooks, etc. are generally approved by the school unit and not by the state, as it is the case in Greece. It is well known that in Greece, with the exception of the hidden curriculum [1], everything else, such as the appointment of teachers, school textbooks used by teachers, curricula, etc. is exclusively a stateowned business.

Thus, in the light of the small scope of the present work, it is noted briefly that the parents' involvement in other countries relates both to school unit and to the home where students work mainly for the purposes of support, improvement and performance of the school unit's work [2]. Specifically, as far as the school is concerned, parents are involved and pronounce upon students' school activities so that a relationship between school and family can be developed [3].

This development occurs because one side (the teachers) listens to the other's (parents') opinion, takes it into account, and thus, they both come together, as far as possible, to make the right decision on school events. Regarding the parents' involvement in home again, this relates to: a) how parents can better care for their children to feel as best ad possible at home as well as at school, b) their children's behavior towards their 
teachers and classmates; c) their children's doing of homework e.tc. [4].

Finally, one could note that parental involvement, regardless of its types (home help, schoolparent communication, volunteering, parent involvement in school activities, home learning, participation in the decisions of school and collaboration with community, municipality, and prefecture [2] that are studied and researched by experts and generally by researchers, is considered necessary and essential to the school and home affairs, because it effectively contributes to the complex and multifaceted work of teachers and the school unit in general [5]. This effectiveness comes about with the adorable cooperation between the school and parents about what goes on in and out of school, which does not happen to the individual and the personal intervention of each parent separately for their own children and nothing more.

Having all the above as a starting point, one could wonder if something similar was happening or happens in Greece as well, despite the occasional remarks being made by experts (mainly educators) and the state through the issuance of presidential decrees, ministerial decisions, etc., where an attempt is made for, even in this way, the important role of the Parents' Association in the educational activities of the school unit to be cultivated.

Unfortunately, the initiatives it undertakes (if it does, because such initiatives are not mentioned by the research participants in this research) are individual rather than collective, without the Parents' Association being informed. This phenomenon (the neglect of the Parents' Association) is conceivable to be also due to that Greek school units are not, as already mentioned, relative autonomous, like in the Anglo-Saxon area. In Greece, a teacher may have a relative autonomy as it has been pointed out in the use of methods, forms, and means of teaching and learning $[1,5]$, but the curricula, teaching and learning contents, textbooks are the sole responsibility of the state, despite the efforts being made from time to time by the State for new textbooks to be created and for teachers to work as autonomously as possible in the school units where they serve.

So one might say, with some reservations, that it would not be right to argue that the Greek parents' intervention in the educational activities of the school unit yields positive results; however, one can safely argue that Greek parents intervene in school acting more individually rather than collectively and more for an individual rather than a collective benefit.

This reality has been the starting point of this small-scale research, the purpose of which is to give a relative picture about cases where parents who have children at school intervene, when they intervene, why they intervene and how these cases are handled by teachers, school principals and generally by all who are involved in the educational activities of a school unit.

Do teachers and general stakeholders (Principals, the Teachers' Associations, Directors of Education, Coordinators of Educational Work) handle these cases with organizational measures, with discussion and understanding, with predetermined visits of parents to the school unit, with invitation in the classroom etc. or in any other way? To investigate such questions and other similar, it was requested from participants in a Master's Degree Program to individually write in 35 minutes anonymously and freely a text about cases of parental involvement in teacher work, given that most of them had experience as teachers, as parents, or as graduates of teacher education departments who, at least in theory, had attended such courses in their departments. However, even if they had not attended such classes, it is not unlikely to have already had a relevant experience from their own school years about parental intervention. The participants' number in the study was 25 .

Thus, having the written text as a research tool, the content analysis method [6-8] was applied, because it provides the opportunity of a full description of the collected material in a systematic way [7]. More specifically, the author who also conducted the analysis of the data, after having read many times the written texts for obtaining a holistic view of the whole, constructed the main categories deductively from the research questions. In a subsequent step, the subcategories were constructed directly from the participants' views from the written texts [7]. As a unit of analysis, a word, a phrase, and a sentence were used [9]. Finally, the following findings resulted which are presented and discussed below.

\section{Analysis, presentation and discussion of the research findings \\ Presentation and discussion of the findings from the involvements of parents \\ From the 25 delivered texts that studied and} analyzed with the content analysis method, it was found that, according to the participants' texts, the most frequent parents' interventions in teachers and in school functioning in general were identified as follows:

In the Teachers' Association decisions about the organization of school celebrations and for the long day trips at the end of the school year. Parents seem to be anxious on the one hand about the fact that their children are not or are fully involved in the implementation of the celebrations, on the other hand, about childrens' safety both on the route and on the accommodation and visitation program set up by the Teachers' Association. Here one might argue that all these happens due to the over-worrying and at the same time caring of parents, a fact that is justified if one takes 
into account the Greek mentality. It is also possible that parents disagree to a certain extent with the Association's decisions, regarding multi-day excursions, also due to their financial burden, especially for the lower social strata due to the economic crisis in Greece, since parental involvement with a positive sign it is almost completely missing from the Greek schools.

In the grades that their children take in school lessons. Parents seem to report that their children are doing well in private lessons and as such they cannot be doing well in school. Parents, therefore, are of the opinion that their children are treated unfairly in the grades they take in their lessons from their teachers compared to their peers or that teachers are unable to identify their children's cognitive background as well as their abilities and skills, and for those reasons parents' strong intervention to educators in terms of grades may be justified. One has to note, however, that parents with a higher educational level seem to intervene more than parents with a lower level [10]. This finding could perhaps be interpreted as a sign that this class of the parents has the impression (false of course) that, because it holds a university degree, it is well placed to assume the important role and the teachers' task which of paramount importance. This intervention, one could also speculate, that occurs more in parents whose children attend the elementary school than in parents whose children attend the middle school and especially high school, because their cognitive background does not leave them in this final educational grade large margins of intervention.

In their concern: a) about their children's stay in school, especially with regard to their children's staying on the full-day program, b) about parents' interventions in the educational process, c) about homework [4] and d) about teachers' behavior towards their children. They report that the teacher treats their children antipedagogically, offends them in front of their classmates, cannot resolve students' conflicts and lacks the proper training to assign and correct homework. They even get to point out to teachers how teachers should behave with students, how to take a lesson and what the spatial arrangement of the classroom should be like. Here, one could justify in an extent the parents' intervention regarding the all-day program, given that the teaching staff has been greatly reduced, compared to its formal introduction in the late 1990s during the ministry of Arsenis [11], the infrastructure is still incomplete, as it was supported by the participants in the present study, and school interference is increasing. Under no circumstances, however, the parents' intervention in matters of pedagogical and teaching nature (homework, many or few, correction, assistance in their execution) can be justified, given that they have neither the pedagogical nor the instructional training of teachers.
In their children's scolding, in the interpersonal relationships of the pupils with each other, and with whom they sit, in the lack of attention and care for their children as well as in matters related to the financial management that the Parents' Association does. Concerning students' interpersonal relationships $[12,13]$, parents may be of the opinion that teachers do not make much effort to develop good interpersonal relationships among their students, possibly due to inadequate pedagogical training and strong interest that teachers show for students to acquire knowledge rather than social and moral values. Although the majority of parents have everything other than pedagogical training, as it has already been pointed out, given that it has not done similar studies, but, even if it did, it does not mean that it can really know what is going on in the classroom, and it thinks it has the right to intervene because they think that teachers are not doing their job well. Here one could also assume that parents do such acts because there is no trust and cooperation between parents and teachers as well as between parents and representatives of the Parents' Association.

In the coverage of the curriculum and the nonimplementation of innovative actions. Parents are anxious about teachers not covering the curriculum, although teachers are largely able to teach by the end of the year what they are required to teach. They also report that teachers do not apply new teaching techniques, do not implement innovative actions and generally the school unit does not operate as it should. Here one has to ask whether and how well the parents are sufficiently informed to be able to judge teachers on such issues.

In the racist reaction of parents, such as the reception of refugees at school, the choice of flag bearer and school violence. Parents seem to be of the opinion that there are cases when their children are annoyed by their peers either due to reasons of the external appearance or due to school performance reasons, etc. and that they react to the reception of refugee students, fearing that they will have a negative impact on their children's performance, behavior, and even on the distortion of the national esprit, religion, etc.. Such behaviors are not appropriate for people like the Greeks who are possessed by feelings of friendship, understanding and love for strangers. Fortunately, cases showing that Greek parents are opposed to receiving foreign students are few and not many. Here one could also mention the example of two elderly women from Lesvos who had shown their love and affection to Syrian refugee infants and had been nominated for peace Nobel prizes. 


\section{Summary}

From the content of the research texts discussed above regarding the parents' intervention in the work of the teachers and the school unit in general and beyond what was discussed, it is generally seen that parents are concerned with their children's ratings (assessment) at school [14], the teachers' antipedagogical behavior, the students' interpersonal relationships, the infrastructure of school unit [15], the non-implementation of innovative educational programs and innovative actions, and finally, the racist behavior [16], and bullying [17].

It also appears that parents: a) operate more individually than collectively as well as for personal gain. It seems that the Parents' Association is bypassed either for personal reasons or because the Association is not functioning properly (not asking parents for school unit decisions, not informing them of issues raised in the school unit, etc.), b) feel insecure about their children and transfer it with their interventions to teachers to school in general, c) they do not trust teachers for the work they do in school classroom d) they do not consider teachers to be adequately qualified, considering themselves to be more experts about many of the actions that teachers do in school, which is unnatural if not irrational, e) they do not cooperate with teachers, a prerequisite for upgrading the educational work of the school unit f) have a fear for their children staying at school, g) they are afraid of diversity, they easily and unknowingly criticize the teaching of teachers, and generally they do not allow teachers to work as they judge, in accordance with the training they have received in their studies and subsequently with their training.

\section{Presentation and discussion of the research conclusions regarding the handling of parental interventions by educators}

In this section are presented and discussed the ways in which teachers handle parents' interventions, according to the views of the research participants. The ways focus on:

Cooperation. Teachers seem to recognize the importance of cooperation in solving school problems, any problems, in this particular case the interventions of parents [18], so they attach great importance to working with parents first and in case this cooperation does not work out to expand it with the principals of the school units and in general with the Teachers' Association. This behavior of teachers shows that teachers behave in a pedagogical way, which would not be a mistake if one asserted that they are provided with sufficient pedagogical training necessary to perform the educational task of school units. By this pedagogical way, parents are more likely to be persuaded that teachers work for the good of their children, to reassure them of any doubts they may have, in order to gain their trust.
The dialogue and the discussion between teachers and parents and then, in case the parents are not satisfied and gratified, the discussion continues, after the principal has been informed by the teacher, between the principal of the school unit and the parents.

If there is still dissatisfaction on the part of the parents, namely they are not satisfied, then the matter is discussed at the Teachers' Association for the appropriate solution to be found. This approach may be judged by those most directly involved in education to be the most appropriate, because they may thus feel that they are helping parents to understand that they are not right and to overcome their anxiety, unjustifiably most of the time, and to come to a loving collaboration between teachers and parents.

Understanding. Teachers, perhaps perceiving the stress and the anxiety that parents have about their children's stay at school and their future in general, and having appropriate pedagogical training, show an understanding of parenting interventions. In this way, thus, their pedagogical training seems inadequate, because with this pedagogical and compassionate way positive outcomes are succeeded rather than in other ways, such as referring to the principal of the School Unit, being aloof to what they say, etc. This does not mean that teachers succumb to the pressure of parents, but that they behave pedagogically, because by this way parents are more likely to understand their mistakes and that they should not interfere with school work.

The parents' informing. Teachers, the school principal and the Teachers' Association in a general plan and implement in-school, out-of-school information sessions in which parents are informed, as well as themselves, about educational, social, etc. issues that concern them and to which parents often refer in their interventions. Initiatives and actions that bring positive results to the pedagogical training of the participants and help them to understand the difficulties teachers have in carrying out their teaching and their educational work in general.

The implementation of the relevant legislative ordinances. Teachers, and generally the school principal and the Teachers' Association, whenever and if they find that they are unable to resolve any problems arising from the parents' interventions, address to their direct supervisors, the Director of Education, the Regional Director of Education, and the Coordinator of the Educational Work. This action shows that those directly involved in the school unit's activities recognize that the problems of the school can be resolved not only by themselves, but also with the help and cooperation of others involved, and they do not lose the opportunity to exploit the knowledge of others who are related to the educational activities of the school unit and generally to education. 
Aloofness and apathy. There are instances, fortunately very few, in which teachers do not behave in a pedagogical and instructive way, showing a complete disregard for what their parents say. This teacher action shows that they are not touched by what parents say, a fact that is antipedagogical, if not unacceptable for a teacher who educates and prepares students for the future. The role of the teacher is not to disregard what students say, even if they exaggerate, but to work with them and to persuade them that what they say, it does not mean that they are true.

\section{Summary}

From the exposition of the ways that teachers and generally all those directly involved in the educational activities of the school unit (teacher, principal, the Teachers' Association) use to deal with parents' interventions, according to the views of the participants in the present study, it can be concluded in general lines that the ways which are implemented are the following: (a) teacher-parent collaboration, teacherprincipal collaboration, principal-parent collaboration; b) the informing of principal and the colleagues of the school unit by classroom teachers, c) the attempt to resolve problems first within the school units with those directly involved (Principal, Teachers' Association, Parents' Association) and then with other stakeholders involved with schools (Directors of Education, Coordinators of the Educational Work, Former School Counselors, etc.), d) the informing of parents, of teachers with lectures and discussions within the school by the same teachers, but also by other special guests.

At this point, one should note, with the exception of the aloofness noted by only a few participants, that the ways with which parental intervention in the teachers' work is handled parent are in general in the right direction.

In particular, it appears that both teachers individually as well as the principal and the Teachers' Association behave pedagogically and democratically in interventions. They are genuinely interested in what they say about (and to) the parents' interventions, although their interventions in most cases may not correspond with the reality. They also show that all those directly involved in the school unit try to resolve any disagreements that parents express about actions that take place in the classroom during the educational process in collaboration, dialogue, understanding and informing parents at the school level unit, but also at the level of Education Directorate and Regional Directorate. So, having in mind the above, one could argue that teachers are wrongly accused of not doing their job well in school, that is, they are not interested in the school curriculum, they are aloof for their students and etc.

\section{CONCLUSION}

The externalizations of the research participants on parenting interventions and their treatment by teachers indicate, on the one hand that most parents' interventions in educational activities of school units are unjustified, without having appropriate and adequate cognitive and pedagogical training, on the other hand the appropriate handling of the parental interventions from a pedagogical point of view by teachers. One should, however, state that, in order to make these findings credible and acceptable, the subject under discussion should be explored using other research methods with a sample consisted of parents who have children in primary and secondary education, pupils and teachers who study and serve at the two school levels respectively, an intention of the researcher to do so in the near future. It is noted, however, that even these research findings of this small-scale research bring into light findings that could be a starting point for further exploration by researchers, since such research is of research interest and can assist both the stakeholders of the school unit and the upgrading of the educational work.

\section{REFERENCES}

1. Jakson, P. (1968). Life in classrooms. New York: Holt, Rinehart and Winston.

2. Epstein, J. L. (1992). School and family partnerships. Baltimore, MD: Johns Hopkins University Center on Families, Communities, Schools, and Children's Learning.

3. Georgiou, S. (2011). Schesi scholeiou-oikogeneias kai anaptyxi tou paidiou [School-family relationship and child's development]. Athina: Diadrasi.

4. Chatzidimou, D. (1995). Oi kat' oikon ergasies ton mathiton sto spiti [The pupils' homework at home]. Thessaloniki: Afoi Kyriakidi Ekdoseis A. E.

5. Chatzidimou, D., \& Chatzidimou, K. (2019). I Ekpaidefsi ton Ekpaideftikon stin Ellada. To paradeigma ton daskalon [The educators' education in Greece: The paradigm of primary school teachers]. Thessaloniki: Afoi Kyriakidi Ekdoseis A. E.

6. Mayring, P. H. (2010). Qualitative Inhaltsanalyse, Grundlagen und Techniken. 11. aktualislierte und ueberarbeiten Aulage. Weinheim und Basel: Beltz.

7. Schreier, M. (2012). Qualitative content analysis in practice. London: Sage.

8. Chatzidimou, K., \& Stamovlasis, D. (2014). Ekpaideftiki Erevna kai Didaktiki tis Glossas. Efarmogi ton archon tis posotikis kai poiotikis methodologias sto erevnitiko pedio tis didaktikis tis glossas [Educational research and the teaching of language. The implementation of the principles of quantitative and qualitative methodology in the research domain of the teaching of language]. Athina: Diadrasi. 
9. Taratori, E. (2004). Daskalos i daskala; Oi mathites epilegoun: Mia pilotiki erevna [Male or female teacher? Students choose: A pilot study]. Sto D. Chatzidimou, E. Taratori, M. Kougiourouki, \& P. Stravakou (Epim.), Praktika 4 ou Panelliniou Synedriou tis Paidagogikis Etaireias Ellados Elliniki Paidagogiki kai Ekpaideftiki Erevna (ss. 757-764). Thessaloniki: Ekdotikos Oikos Adelfon Kyriakidi.

10. Bampalis, T. H., \& Kirkigianni, F. (2011). O rolos tou diefthynti stin epikoinonia tou scholeiou me tous emplekomenous goneis [Principal's role in school's communication with the involved parents]. Paidagogiki Epitheorisi, 52, 118-133.

11. Chatzidimou, D. (2019). I ekpaideftiki politiki kata tin teleftaia triakontaetia gia ti domisi enos montelou Oloimerou Dimotikou Scholeiou stin Ellada: proodos kai palindromisi [The educational policy during the last thirty years for the construction of a model about the full-time primary school in Greece: Progress and regression]. Sto: Omilos Protovoulias gia tin Elliniki Paideia. Ekpaideftiki Metarrythmisi \& Ekpaideftiki Politiki, timitiko afieroma sti mnimi tou Gerasimou Arseni (s.s. 203-230). Athina: Gutenberg.

12. Karamane, E. (2019). Antilipseis mathiton kai ekpaideftikon gia ti diaprosopiki symperifora tou ekpaideftikou sti scholiki taxi [Perceptiond of students and educators about the educator's interpersonal behavior in classroom] (Adimosiefti didaktoriki diatrivi). Aristoteleio Panepistimio Thessalonikis.

13. Bikos, K. (2011). Koinonikes scheseis kai allilepidrasi sti scholiki taxi [Social relationships and interaction in school classroom]. Thessaloniki: Zygos.

14. Taratori-Tsalkatidou, E. (2003). A pupil's school achievement and the contribution of the family The results of a survey. Kinitro, 5, 125-136.

15. Demiroglou, P., \& Paschalidis, N. (2013). Erevnitika dedomena apo ti dierevnisi tou deikti «Scheseis metaxy scholeiou - goneon» sto plaisio tis efarmogis tou pilotikou programmatos «Axiologisi tou ekpaideftikou ergou tis scholikis monadas kai diadikasia tis aftoaxiologisis»: I periptosi enos scholeiou agrotikis periochis [Research data from the investigation of the indicator of the "Relationships between school parents" in the context of the implementation of the pilot program "The assessment of the school unit's educational work and process of selfassessment": The case of a rural school. Kinitro, 12, 93-108.

16. Taquieff, P. A. (1998). O ratsismos. Mia anaptyxi gia katanoisi - mia meleti gia stochasmo [The racism. A development for understanding - a study for reflection]. Mtfr. G. Spanos. Athina: Travlos.

17. Rigby, K. (2008). Scholikos ekfovismos: Synchrones apopseis [School bullying: Contemporary views]. Mtfr. Vasiliki Dompola, epim. A. Giovazolias. Athina: Topos.

18. Stravakou, P., \& Lozgka, E. (2017). Scheseis goneon kai ekpaideftikon-Mia poiotiki erevna [Parents-educators relationships-A qualitative research]. Sto: K. Sarafidou (Epim.), Synchrones Taseis kai Praktikes sti Diacheirisi tis Scholikis Taxis (s.s. 832-840). Drama: Etaireia Epistimon Agogis Drama. 